\title{
The Great Tew Circle, 1630-1639
}

\author{
By Michael J. Langford*
}

The Great Tew Circle comprised a group of theologians, philosophers and poets who met regularly in Lord Falkland's house at Great Tew, near Oxford, from the early 1630s until around 1639. Although strongly royalist and Anglican, on many matters, especially that of toleration, they defended views that would later be classed as liberal. ${ }^{1}$ This article introduces the reader to the Great Tew Circle, and explores its relationship with the better-known Cambridge Platonists, most of whom flourished a few decades later. Common ground included the influence of Plato and an appeal to 'reason', although exactly how reason should to be understood raises interesting issues.

\section{Introduction}

The Great Tew Circle comprised a collection of theologians, philosophers and poets who met together in Lord Falkland's house at Great Tew, about sixteen miles from Oxford, from the early 1630s until around 1639 when rumbles of the civil war - which broke out in 1642 -- summoned Falkland to matters of state, and the group discussions were discontinued. Thereafter, despite the deaths of Falkland and Chillingworth, the Circle maintained some influence and a degree of association between many of its members remained, in part through the continued patronage of Falkland's widow. At first sight, the Restoration of Charles II in 1660 might seem to mark a kind of success for the aspirations of the Circle, and particularly for the efforts of Henry Hammond during the Commonwealth period, but although the return to monarchy and state Anglicanism did represent some aspects of the Circle's agenda, the generally narrow and intolerant agenda of the new order certainly did not.

Both Lord Clarendon (Edward Hyde) in his Life, ${ }^{2}$ and John Aubrey (1626-97) in his Brief Lives, provide lists of the collection of stars who were members of the Circle, all of whom were friends of Falkland, although -- as the historian TrevorRoper warns us, in his chapter on the Great Tew Circle -- not all of his friends were 'members' of the Circle. ${ }^{3}$ In addition to Lord Falkland (Lucius Cary), key

\footnotetext{
*Emeritus Professor of Philosophy, The Memorial University of Newfoundland, Canada, and Faculty of Divinity, University of Cambridge, UK.

1. In the seventeenth century the word 'liberal' tended to mean 'given to generosity', or to refer to the traditional 'liberal arts', but since the late eighteenth century (according to the Oxford English Dictionary) it has also been used to mean 'free from narrow prejudice, open-minded, candid'. In accordance with this later usage, the term 'liberal theology' has been used to refer to styles of theology that seek bridges with different faith systems and stress the metaphorical rather than the literal use of sacred writings. Formerly, the term 'latitudinarian' tended to be used for this.

2. Edward Hyde (Lord Clarendon), Life (Oxford: 1760), ps. $29 \mathrm{ff}$.

3. H. Trevor-Roper, Catholics, Anglicans and Puritans: Seventeenth Century Essays (London: Fontana, 1989), p. 171 note.
} 
figures included William Chillingworth, who along with Ben Jonson were perhaps the most renowned members of the Circle -- other than Thomas Hobbes, who was often there, but was not really a 'member' in terms of his overall philosophy. ${ }^{4}$ William Chillingworth wrote most of his hugely influential The Religion of Protestants (1638) at the house. Others members included John Hales of Eton, John Earle (or Earles, who, as Bishop of Salisbury, after the Restoration, worked for reconciliation with non-conformists), Gilbert Sheldon (later Archbishop of Canterbury), Robert Boyle, Sidney Godolphin, Henry Hammond, Edmund Waller and Hugh Cressy (who later, in the language of the time, 'perverted' to Rome and became a polemicist). Clarendon, a close friend of Falkland's, describes the atmosphere as "one continued convivium philosophicum or convivium theologicum" and adds "nor did the lord of the house know of the comings and goings, nor who were in his house, till he came down to dinner or supper, where all still met." ${ }^{5}$ The intellectual activity was supported by the excellent library held at the house.

Given the nature of this group, notably its rationalizing nature and -- as Trevor-Roper points out ${ }^{6}$-- its intrinsic quality, one of the questions that arises is: "What was the Great Tew Circle's relationship to the Cambridge Platonists, many of whom were active shortly after the demise of the Circle?"

\section{The Beginnings of a Plausible Answer is Provided by the Scottish Theologian John Tulloch (1823-86)}

In the introduction to his volume on the Cambridge Platonists he writes: "There is even good reason to conclude that the ultra-dogmatic character of the Westminster Confession of Faith was itself among the chief reasons of the reaction to a more liberal theology" (p. 11). ${ }^{7}$ Although this Confession (1646) was produced after the Great Tew Circle had been wound up, there can be little doubt that its members were similarly inspired, in part, by an equivalent reaction to what was seen as unnecessarily dogmatic and divisive forms of Christianity -- reflecting

4. M.L. Donnelly has argued for a closer association of Hobbes with the Great Tew Circle in the context of his argument that the Circle was influential in advancing a neoclassical aesthetic. See his "The Great Difference of Time: The Great Tew Circle and the Emergence of the Neoclassical Mode," in Claude J. Summers and Ted-Larry Pebworth (eds.) Literary Circles and Cultural Communities in Renaissance England (London: University of Missouri Press, 2000).

5. Edward Hyde, Life, p. 33.

6. Trevor-Roper, Ibid, p. 175.

7. John Tulloch, Rational Theology and Christian Philosophy in England in the Seventeenth Century (Edinburgh: Blackwood, 1872), vol. 2. Note, in particular, these two articles from the Westminster Confession: "By the decree of God, for the manifestation of His Glory, some men and angels are predestined unto everlasting life; and others foreordained to everlasting death" [III, 3], and "They [Adam and Eve] being the root of all mankind, the guilt of their sin was imputed ... and ... conveyed to all their posterity" [VI, 3]. Elsewhere, I have criticized the Western doctrine of original guilt, defending instead the Greek Orthodox account of an 'original sin' that sees a stain of 'weakness' but not 'guilt' in the newborn, and quoted Abelard and Jeremy Taylor as rare, pre-nineteenth century Western representatives of a similar view. See Michael J. Langford, The Tradition of Liberal Theology (Grand Rapids: Eerdmans, 2014). 
Richard Hooker's earlier rejection of both hard-line Calvinism and orthodox Catholicism. In the case of the Great Tew Circle, instead of the Westminster Confession we may point to the decrees of the Synod of Dort, 1618-9, as a major cause of irritation. John Hales, although not an official deputy, attended this synod and wrote extensive reports on its meetings to the English ambassador at The Hague, Sir Dudley Carlton. ${ }^{8}$

However, despite the common source of the two movements in the rejection of Calvinism and in an eirenic response to church divisions, Tulloch argues that a much more speculative atmosphere permeates the later, Cambridge Platonist movement: "In their writings we pass into a higher, if not more bracing, atmosphere than that in which we have been dwelling in the pages of Hales and Chillingworth. They discussed larger questions and principles of a more fundamental and far-reaching character" (ps. 13-14). In Cambridge Platonism he sees "the first elaborate attempt to wed Christianity and philosophy made by any Protestant school", and he adds "it may be even said to have been the first true attempt of the kind since the days of the great Alexandrine teachers" (p. 14). Tulloch adds a footnote here: "The Florentine movement in the latter part of the fifteenth century is hardly an exception. Marsilius Ficinus and the two Pici of Mirandola -- uncle and nephew -- were not theologians, although animated by a profound theological instinct. The Academy of the Medici, of which they were the ornaments, was, in part at least, literary and humanistic in its tendencies."

This wider philosophical concern, which Tulloch attributes to the Cambridge Platonists but not to the Great Tew Circle, is also based, he maintains, on the growing influence, in Cambridge, of both Bacon and Descartes. Bacon's Novum Organon, first appeared in 1620, but Tulloch argues that for some twenty years, it was largely ignored in favour of an old-fashioned scholasticism (p. 15). Bacon's philosophy - it should be noted -- was not an influence in terms of agreement, but in large part, of reaction, especially in the light of his divorce between philosophy and theology. Rather later did Descartes begin to be studied seriously in Cambridge, as witnessed by Henry More's interest in him (p. 17).

The theologian (Dean) W.R. Inge (1860-1954) suggests a similar relationship between Great Tew and the Cambridge Platonists. He writes: "After the Reformation there was an important ecclesiastical movement in the direction of liberalism, comprehension, and toleration, which has no intimate connexion [sic] with the Platonic tradition, though the two naturally appealed to the same type of mind. The chief names are Lord Falkland, Hales of Eton, Chillingworth, and Stillingfleet, with whom, I think, Jeremy Taylor may be associated. The philosophical movement [i.e. the Cambridge Platonists] followed." ${ }^{9}$ It should be noted that neither Edward Stillingfleet nor Jeremy Taylor were part of the Great

8. John Hales, Works, 1765, III p. 59. [The pagination in volume 3 restarts with the Letters from the Synod of Dort.] Because of the tediousness of some debates Hales admits to sometimes falling asleep and on these occasions only being able to provide a 'thread'.

9. W.R. Inge, The Platonic Tradition in English Religious Thought (London: Longmans, Green and Co, 1926), p. 39. 
Tew Circle, although they certainly supported its liberalism and Stillingfleet quotes both Chillingworth and Hales. ${ }^{10}$

Yet further evidence for the more philosophical approach of the Cambridge Platonists is provided by a comment made after the Reformation by Gilbert Sheldon when Archbishop of Canterbury. He intimated to the Platonist, Henry More, that he was disposed to look up to "the new 'free method of philosophizing' with far from unfriendly sentiments -- provided the faith, the peace, and the institution of the Church were not thereby menaced." 11

The suggestion, in both Tulloch and Inge, is that while both movements had in common a moderation and an appeal to rationality (in contrast with the pronouncements of either the Synod of Dort or the Westminster Confession) the Great Tew Circle was more theological and more concerned with church divisions than it was philosophical in general, or Platonic in particular -- in contrast with the Cambridge Platonists. In an attempt to see if this view could be tested I undertook a scan of the published works of John Hales of Eton -- or more strictly of the three volumes of his Works in the Glasgow edition of 1765, reprinted in New York in 1971. I chose John Hales of Eton, in part because he was acknowledged to be one of the most learned of the Circle, and in part because he was, for a time, Regius professor of Greek at Oxford, who could therefore be expected to be thoroughly familiar with the Platonic corpus. I came up with the following results. There were numerous quotations in Greek, usually appended to notes at the bottom of the page, with many references to Aristotle and Homer, and occasional references to (among others) Hippocrates (II, 12, 34), Epictetus (II, 88, 169), Euripides (II, 144), Aristophanes (II, 231), Aeschylus (II, 305), Sophocles (III, 149), Thucydides (III, 144), Protagoras (II, 89), as well as many to Chrysostom who was a special object of his study, and Basil; but only one to Plato, and that was in Hales's letters describing the Synod of Dort in a passage in which he is summarizing a speech by Episcopius. ${ }^{12}$ The only other things I found that related directly to the Platonic tradition were a reference to Porphyry ( $\mathrm{I} ;$ p. 93) -- which is, by implication -somewhat uncomplimentary, and perhaps more significantly, a reference to two 'emanations' during a discussion of the Trinity. ${ }^{13}$

However, it is too soon to conclude that Plato was more or less absent in terms of first-hand influence, particularly in the light of a suggestion by the author

10. Tulloch, vol. I, p. 460.

11. N. Tyacke (ed.), The History of the University of Oxford, vol. IV (Oxford: Clarendon Press, 1997), p. 423.

12. John Hales, Ibid, p. 74. Episcopius's speech includes the words Amicus Socrates, amicus Plato, amica synodus, sed magis amica veritas. Simon Episcopius was one of the 'Remonstrant' (Arminian) representatives at the Synod who -- after the deliberations -- were deprived of their offices.

13. In this Trinity there is one essence: two emanations: three persons, or relations; four properties, five notions," and a little later: "The two emanations are, to be begotten: and to proceed, or to be breathed out ... " (vol. I, ps. 76-7). The notion of 'emanations' is strongly evocative, not of Plato himself, but of Neo-Platonism - a tradition that was of interest to scholars of both the Great Tew Circle and the Cambridge Platonists. 
of the Dictionary of National Biography on Clarendon (Paul Seaward) that Edward Hyde was "spurred by Falkland's reading in Plato" to consider issues of authority and reason. ${ }^{14}$

Trevor-Roper provides a list of the sources used by the Great Tew Circle, noting especially Erasmus, Sebastian Castellio, du Plessis-Mornay (the influential Huguenot writer), Socinus, Acontius, ${ }^{15}$ Hooker and Hugo Grotius. The last two were of special importance and of most frequent quotation. Grotius was the principal source for the Great Tew Circle's knowledge of Arminianism. In the case of Chillingworth Trevor-Roper should also have mentioned the multiple references to Augustine.

Prior to an examination of the published works of all the other members of the Circle, my suspicion is that the influence of Plato was twofold; first, in terms of a general rationality (as in the 'natural theology' of Plato's Laws, book 10), a rationality that characterized all members of the Circle; second, in terms of a belief in the intimate connection of rationality with moral character (reflecting Plato's intimate connection between knowledge and virtue). John Hales, for example, writes of "that faculty of reason which is in every one of you, even in the meanest that hears me this day, next to the help of God, is your eyes to direct you, and your legs to support you in your course of integrity and sanctity ..." ${ }^{16}$ In the case of the Cambridge Platonists, in addition to these two influences, we find a third, especially with Cudworth, in the detailed analysis of Plato's metaphysics and the different ways in which Plato uses theos, for example, in the distinction between the eternal God and the gods that are 'generated'. ${ }^{17}$

Closely related to the theme of rationality is the charge of Socinianism that was frequently laid against the Great Tew Circle. Here Clarendon is specially helpful, pointing out that the charge tended to mean two very different things; first a general support for reason, in contrast with a Calvinist doctrine of total depravity that rendered any such reliance on human reason suspect, and second, a specific unorthodoxy with respect to the doctrine of the Trinity. ${ }^{18}$ References to Socinus in

14. So far, I have been unable to find documentary evidence for this claim.

15. Jacobus Acontius (Aconsio), who was probably born around 1500 (though some authorities think as late as 1520) and died in 1566 or 7, was an Italian jurist and polymath who converted to a liberal form of Protestantism. He came to England shortly after the accession of Elizabeth (1558) where he was employed because of his engineering skills (in drainage and in the fortifications at Berwick). His Stratagematum Satanae, 1565, is one of the classics of Christian appeals for toleration, along with Sebastian Castellio's De Haereticis, an sint persequendi of 1554. Persecution is part of Satan's strategy. English versions, Darkness Discovered, date from 1647. Early versions of this translation omit the later chapters, 5-8, which were more obviously critical of Calvinism.

16. John Hales, Works, 1765, III, p. 156.

17. Ralph Cudworth, The True Intellectual System of the Universe (London, 1678), chapter 4, section XIV. In the Preface to this work Cudworth argues that there is a true Trinity to be discerned in Plato's writings (as well as some 'trinities' that do not correspond to it).

18. "In this Trinity there is one essence: two emanations: three persons, or relations; four properties, five notions," and a little later: "The two emanations are, to be begotten: and to proceed, or to be breathed out ... " (vol. I, ps. 76-7). The notion of 'emanations' is, of course, strongly evocative, not of Plato himself, but of Neo-Platonism. 
one's writings in no way entails agreement with all his views. With respect to the first sense of the term, to a man, the Great Tew Circle did espouse this view; with respect to the second (and much more accurate use of the adjective 'Socinian'), they were strongly opposed -- manifesting a traditional Trinitarian orthodoxy although in the case of Chillingworth - with some hesitation, as we shall see. John McLachlan suggests that the charge of Socinianism was given credence, in part, because some clearly Socinian tracts were wrongly attributed to Hales and Chillingworth. ${ }^{19}$ In the case of Falkland, John Aubrey, in his brief account of his life, describes him as "the first Socinian in England" and refers to Cressy's claim (made in 1669) that Falkland was the first to bring Socinius's books into England. However, there is no reason to think that Falkland was a Socinian in the second, and proper sense of the term.

The issue of the manner in which Socinianism either influenced or characterized the Great Tew Circle has been subjected to a useful analysis in Sarah Mortimer's Reason and Revolution in the English Revolution. ${ }^{20}$ What becomes evident from this study is that the influence of Socinus on the Great Tew circle was more than a general emphasis on 'reason' - and it may well be the case that in the case of Chillingworth his devotion to reason led him to hesitate before officially approving Anglican statements regarding the Trinity. Here his position was different from the more traditional stance of Falkland. Not only does Trinitarian doctrine find little emphasis in The Religion of Protestants, Chillingworth's reluctance to accept patronage, including the chancellorship of Sarum, until $1638,{ }^{21}$ was related to his doubts about affirming the 39 Articles, in which an orthodox Trinitarianism is affirmed. Following correspondence with Sheldon, Chillingworth was eventually persuaded to accept the 39 Articles -- as was legally required for preferment -- in part because this was interpreted as a kind of general acceptance of the underlying principles rather than a reference to the precise wording of each Article.

Of more impact than qualms about Trinitarianism, however, was the Socinian distinction between natural law and the law of Christ, revealed in the New Testament, and the corresponding topic of obedience to political authority. Most expositions of natural law (rooted in the ius naturale of Roman Law and the lex naturalis of Aquinas) gave criteria for when a war could be just, and for many writers, including John Milton, an extension of the same arguments applied to revolutions, in which - in 'just' cases - magistrates (or more rarely, the people) could rise up against their tyrannical overlords. Faustus Sozzini (the younger Socinus) argued that although such rebellion might be allowed under natural law, and although God actually permitted or even commanded some such rebellions in the Old Testament, the revealed law of Christ had changed the situation. ${ }^{22}$ Christ accepted the rule of Caesar, and Christians should accept even tyrannical kings.

19. H. John McLachlan, Socinianism in Seventeenth Century England (Oxford: Oxford University Press, 1951), ps. 74-8.

20. Sarah Mortimer, Reason and Religion in the English Revolution: The Challenge of Socinianism (Cambridge: Cambridge University Press, 2010).

21. See Tulloch, op. cit. vol. 1, ps. 282-87, 292-3.

22. See Mortimer, op. cit. p. 88. 
The Great Tew Circle's support for the royalist cause - reluctant as it was in many cases - was rooted in this rejection of the natural law argument for a just rebellion used by Cromwell and his followers.

This issue highlights a tension within the philosophy of the Great Tew Circle. The more one stresses a general rationality as a source of knowledge, over against revelation or alleged revelation, the more one might seem likely to approve an overarching natural moral law that was open to all people of good will. The general tendency of the sermons preached by members of the Great Tew Circle to emphasize the ethical aspects of Christianity also supports this emphasis. However, this emphasis does not sit easily with the special claims of an allegedly different and more demanding 'law of Christ'. The tension becomes even more evident when this law of Christ does not lead one to outright pacifism, as it did for Faustus Sozzini as well as for most Quakers (some, like Isaac Penington excepted), but to military support for the royalist cause.

The theme of rationality is also linked to that of toleration, and here - I suggest - the Great Tew Circle deserves considerable credit. In 1643, on his deathbed, Chillingworth was pressed by the Puritan, Francis Cheynell, to withdraw his claim that Muslims (he used the term 'Turks'), Roman Catholics and heretics, if they genuinely endeavored to do what is good, could be saved. This is to respond to the 'word' of God. Chillingworth refused to do so. ${ }^{23}$ Today, his claim might seem natural, even obvious, but we need to realize how extraordinary it seemed to most people of the time, given the narrowness of so many religious people.

In the context of his writings we can understand the reason for Chillingworth's refusal to withdraw his claim. He held the view -- ultimately derived, in all probability -- from an Alexandrine Christian tradition (notably in the writings of Origen) that goes back to the second and third centuries, that people who truly respond to God's logos, or 'word', as it comes to them in the form of the Good, the True and the Beautiful, are indeed responding to the logos. Christianity is unique in articulating that the logos was made flesh in the person of Jesus, but this does not mean that only Christians are responsive to God's Word. In addition to God's grace, the one, absolutely essential thing required for salvation, Chillingworth claimed, is to endeavor to do the good, as one sees it. ${ }^{24}$ This is to respond to the 'word' of God. It was a similar insight that allowed Justin Martyr, writing about 151-5 CE, to claim: "those who live with the logos are Christians, even though they have been called atheists". ${ }^{25}$

Further, we find Chillingworth quoting Hooker's exact expression on the difference between 'Certainty of Evidence' (which we do not have) and 'Certainty of Adherence' (which we can acquire - and which we could liken to

23. F. Cheynell, Chillingworthi Novisssima (London: 1644), 44. See also R.R. Orr, Reason and Authority (Oxford: Clarendon Press, 1967), 163.

24. Chillingworth, The Religion of Protestants, 3, 14. p. 135. "... if we do indeed desire and endeavour to find the truth, we may be sure we do so, and be sure that it cannot consist with the revealed goodness of God, to damn him for error, that desires and endeavours to find the truth." cf. 2 , 104 , p. 92 and 3, 52, ps. 158-160.

25. Justin Martyr, First Apology, ch. 46. 
'conviction'). ${ }^{26}$ Again, when he speaks of a 'tyrannical God' who condemns those who make honest mistakes -- a view of God he finds on both sides of the polemical debate -- he adds the comment: "I for my part fear I should not love God, if I should think so strangely of him". ${ }^{27}$ Congruently, in his defense of toleration, he condemns the use of violence and of "Machiavillian police" [sic] in order to make people conform in matters of religion, which can so easily "make men counterfeit". ${ }^{28}$ Here we see clearly the influence of Acontius, and very likely of Sebastian Castellio as well.

If we seek to explore further what 'Platonism' implies, whether in the case of the Great Tew Circle or the Cambridge Platonists, one interesting line of investigation is to examine the relation of metaphysics to mathematics (potentially an additional aspect of Platonism). For Plato, ta mathematica, in the simile of the line, occupies an intriguing half way position between opinion and true knowledge. In the Platonism of Nicholas of Cusa (1401-64) there is a correspondding use of mathematics as a kind of bridge between ordinary human thinking (characterized by his use of ratio) and true intellectual vision (characterized by his use of intellectus). ${ }^{29}$ In contrast, although Chillingworth was a gifted mathematician, he does not use mathematics to make any metaphysical argument, and tellingly, he contrasts the kind of 'discerning judgment' of many fine mathematicians who are - nevertheless - 'utterly imprudent', with the wisdom of the truly prudent, "because Prudence requires not only a good discerning judgment and apprehension [which mathematicians have], but a serenity and calmness of the passions." ${ }^{30}$ I found an interesting parallel in Cudworth - again a man said to be gifted in mathematics, but who refers in one passage to "mere speculation and dry mathematical reason, in minds unpurified, and having contrary interests of carnality .... [which] cannot alone beget an unshaken confidence and assurance of so high a truth as this, the existence of a perfect understanding Being, the original of all things." ${ }^{31}$ This theme of the interconnection between rationality and ethics is one where there is certainly common ground, if not influence, between the Great Tew Circle and the Cambridge Platonists. In the latter, it is specially evident in the writings of John Smith (1618-52), who writes: "it is the heart that sends up good blood and warm spirits in to the head, whereby it is best enabled to its several

26. Chillingworth, The Religion of Protestants (Oxford, 1638), 1, 9, p. 37; 2, 154, p. 112. cf. A Hooker sermon of c. 1585 in Works (3rd ed. ed. Keble, 1845), vol. III, ps. 470-1.

27. Chillingworth, The Religion of Protestants, 2, 104, p. 92.

28 Chillingworth, The Religion of Protestants, 5, 96, p. 297.

29. It is the latter that denies the oppositions proposed by reason, and hence Cusa's famous claim about the coincidentia oppositorum - an insight only achievable by intellectus. Cusa's frequent excursions into mathematics are an important element in his Platonism, not primarily on account of his strictly mathematical writings, but because of the way he uses mathematical argument within his theology, for example, in his use of 'triangularity'. On the relation of ratio to intellectus in Cusa see Michael. J. Langford, "Premodern dialogue with special reference to Nicholas of Cusa," in The Medieval History Journal, 20, no. 1 (2017), ps. 118-147.

30. Chillingworth, Sermon 2, paragraph 29. One of John Hales's letters discusses triangularity, but with no reference to any metaphysical implications or parallels. See his Works, vol. 1, ps. 194-6.

31. Cudworth, Preface to The True Intellectual System of the Universe. 
functions; so that which enables us to know and understand aright in the things of God, must be a living principle of holiness within us." ${ }^{32}$

One clear difference between the Great Tew Circle and the Cambridge Platonists relates to their different responses to the revolution of 1642, and the different treatments by the Commonwealth authorities. The Great Tew Circle supported the royalist cause while those Cambridge Platonists who were fellows or masters of colleges maintained their positions, although some of them, including Benjamin Whichcote, managed to avoid actually taking the Covenant of 1643. However, this difference, though real, was not as sharp as might be supposed, because (i) both Falkland and Chillingworth were highly critical of much of the royalist rhetoric (as evidenced by Falkland's despair on the battlefield, and Chillingworth's unpopular sermons to the royal army), and (ii) many of the Cambridge Platonists argued strongly for more toleration than most Presbyterians wanted to allow.

There is more work to be done in exploring the relationship between the Great Tew Circle and the Cambridge Platonists, including: (i), an exploration of letters in various archives and publications; (ii), an examination of library holdings in the 1630s; (iii), a search for citations in all the members of the Circle along the lines of my examination of John Hales; (iv) a further search for Platonic themes that are not necessarily discernible from quotations; and (v), the way in which all the Circle members used Richard Hooker.

\section{Postscript}

Chillingworth's claim that the one thing needful for salvation is to 'endeavour' to do the good, as one sees it, while attractive, raises a difficulty that needs some comment. This claim, like that of Kant when he claims that the only thing good without qualification is 'the good will', can appear to approve the actions of 'fanatics', provided only that -- however mistaken -- (i) they genuinely believe that they are doing the right thing, and (ii) that their motive is simply and entirely to do the right thing (and not, for example, the intention of being rewarded in heaven). Quite apart from any evaluation of liberal theology, this is a serious issue in moral philosophy. Arguably, Chillingworth's claim can only be supported within a wider discussion concerning the nature of the good. In addition to the demand to endeavour to follow the good, we also have a responsibility to develop some coherent notion of what the good is. This can be found, in part, through Aristotle's emphasis on the need to acquire genuine virtue through how we manage our whole lives, which will hugely affect how we see 'the good', and in part by stressing Aristotle's claim that we have the potentiality to respond to the 'eye for the good', with which the virtuous person is endowed by nature (Nicomachean Ethics,

32. John Smith, Select Discourses (London: 1660), p. 3. 
1114a-b.). If we support Chillingworth's claim that it makes no moral sense to think that a good God will condemn sincere followers of other 'ways' or dao, it does not follow that right intention, or endeavour is the only thing needful. Further, the kinds of people Chillingworth has in mind are typical examples of 'good' Muslims and Jews (and we should add, secular humanists) who follow the Golden Rule, and who are as likely to be horrified by the actions of fanatics as are liberal Christians. The situation is paralleled by the distinction between 'conscience' -- when used to refer simply to a momentary feeling -- and the kind of developed 'conscience' described in Bishop Joseph Butler's account of reflecting in 'a cool hour'; and also in the medieval distinction between conscientia and synderesis.

\section{Bibliography}

Jacobus Acontius (Aconsio), Stratagematum Satanae, 1565. English tr. Darkness discovered, London, 1651.

Aristotle, Nicomachean Ethics.

Aubrey, John. Brief Lives (written 1669-1697). edited by A. Powell. London: Cresset Press, 1949.

Castellio (Chataillon), Sebastian. De hereticis an sint persequendi, (1554) edited and translated by R.H. Bainton. New York: Columbia University Press, 1935.

Cheynell, F. Chillingworthi Novisssima. London, 1644.

Chillingworth, William. The Religion of Protestants. Oxford, 1638.

Cudworth, Ralph. The True Intellectual System of the Universe. London, 1678.

Donnelly, M.L. "The Great Difference of Time: The Great Tew Circle and the Emergence of the Neoclassical Mode." In Claude J. Summers and Ted-Larry Pebworth (eds.) Literary Circles and Cultural Communities in Renaissance England. London: University of Missouri Press, 2000.

George, E.A. Seventeenth Century Men of Latitude. London: Fisher and Unwin, 1909.

Hales, John. Works, 3 vols. Glasgow, 1765.

Hooker, Richard. Works, $3^{\text {rd }}$ ed. edited by Keble. Oxford: Oxford University Press, 1845.

Hyde, Edward (Lord Clarendon). Life. Oxford: 1760.

Inge, W.R. The Platonic Tradition in English Religious Thought. London: Longmans, Green and Co, 1926.

Justin Martyr. Writings, translated by T.B. Falls. Washington, DC: The Catholic University of America Press, 1948.

Mullinger, J.B. The University of Cambridge. Cambridge: Cambridge University Press, 1911. Vol. 3, ps. 588-662 (for vignettes of Cambridge Platonists).

Langford, Michael J. The Tradition of Liberal Theology. Grand Rapids: Eerdmans, 2014.

Langford, Michael J. "Premodern dialogue with special reference to Nicholas of Cusa." In The Medieval History Journal, 20, no. 1 (2017).

McLachlan, H. John. Socinianism in Seventeenth Century England. Oxford: Oxford University Press, 1951.

Mortimer, Sarah. Reason and Religion in the English Revolution: The Challenge of Socinianism. Cambridge: Cambridge University Press, 2010.

Orr, R.R. Reason and Authority. Oxford: Clarendon Press, 1967. 
Smith, John. Select Discourses. London: 1660.

Seward, Paul. entry on Edward Hyde (Lord Clarendon) in Dictionary of National Biography. Oxford: Oxford University Press, 2004, vol. 29.

Stillingfleet, Edward. Irenicum (London: 1661).

Trevor-Roper, H. Catholics, Anglicans and Puritans: Seventeenth Century Essays London: Fontana, 1989.

Tulloch, John Rational Theology and Christian Philosophy in England in the Seventeenth Century. Edinburgh: Blackwood, 1872, 2 vols.

Tyacke, N. (ed.). The History of the University of Oxford, vol. 4. Oxford: Clarendon Press, 1997. 
